\title{
Implikasi Yuridis Terhadap Bank Akibat Penurunan Status Perjanjian Kredit dari Akta Otentik Menjadi Akta di Bawah Tangan
}

\author{
Aisyah Ayu Musyafah ${ }^{1}$ \\ Fakultas Hukum Universitas Diponegoro \\ JL. Prof. Sudharto No. 1 Semarang, Jawa Tengah, 50275 \\ aisyahayumusyafah@gmail.com
}

\begin{abstract}
The purpose of this research is to investigate and study the factors that led to the Notary signed a deed of credit agreement without the presence of the parties before him that expressly violates the provisions of the legislation, as well as to identify and assess the legal consequences faced by banks as creditors due to a decrease in status credit agreement of the authentic act becomes deed under the hand because of the absence of the parties before the Notary. This type of research is normative empirical. Empirical research normative law is essentially a merger between the normative legal approach with the addition of various elements of the empirical. This research is descriptive of the type of research that aim to present a complete picture of the problem. Analysis of the data in this study using qualitative methods, the choice of data obtained from research based on quality or quality. Factors causing the Notary deed signed a credit agreement without the presence of the parties before him that expressly violates the provisions of the legislation that is due to too many certificates must Notary made and it was done because it was approved by the bank concerned and also to demand the bank. The legal consequences faced by banks as creditors due to a decrease in the status of a credit agreement of the authentic act into a deed under the hand because of the absence of the parties before the Notary, namely the decrease in the strength of evidence of the authentic act which has the strength of evidence may be perfect in deed under the hand that has the strength of evidence imperfect. Credit agreements in the form of a deed under the hand, the burden of proof is on the bank. In contrast to authentic deeds, to prove that an obligation on the parties deny the authentic act. Credit agreements or signatures that are not recognized by the debtor and the judge granted, the bank can not execute a guarantee for the debts of the debtor. Banks also have to spend more for the court proceedings and can damage the bank's reputation.
\end{abstract}

Keywords: notary, banks, credit agreement, authentic deed, private deed.

\begin{abstract}
ABSTRAK
Tujuan dari Penelitian ini adalah untuk mengetahui dan mengkaji faktor-faktor yang menyebabkan Notaris melakukan penandatanganan akta perjanjian kredit tanpa kehadiran para pihak dihadapannya yang secara tegas melanggar ketentuan peraturan perundang-undangan, serta untuk mengetahui dan mengkaji konsekuensi hukum yang dihadapi bank sebagai kreditur akibat penurunan status perjanjian kredit dari akta otentik menjadi akta di bawah tangan karena ketidakhadiran para pihak di hadapan Notaris. Jenis penelitian ini yaitu normatif empiris. Penelitian hukum normatif empiris ini pada dasarnya merupakan penggabungan antara pendekatan hukum normatif dengan adanya penambahan berbagai unsur empiris. Penelitian ini bersifat deskriptif yaitu satu jenis penelitian yang tujuannya untuk menyajikan gambaran lengkap mengenai suatu permasalahan. Analisis data pada penelitian ini menggunakan metode kualitatif yaitu pemilihan terhadap data yang diperoleh dari penelitian berdasarkan mutu atau kualitasnya. Faktor penyebab
\end{abstract}

\footnotetext{
${ }^{1}$ Dosen Hukum Perdata, Fakultas Hukum UNDIP, Semarang
} 
Notaris menandatangani akta perjanjian kredit tanpa kehadiran para pihak dihadapannya yang secara tegas melanggar ketentuan peraturan perundang-undangan yaitu dikarenakan terlalu banyak akta yang harus Notaris buat dan hal itu dilakukan karena telah mendapat persetujuan dari bank yang bersangkutan dan juga dikarenakan permintaan pihak bank. Konsekuensi hukum yang dihadapi bank sebagai kreditur akibat penurunan status perjanjian kredit dari akta otentik menjadi akta di bawah tangan karena ketidakhadiran para pihak di hadapan Notaris, yaitu terjadinya penurunan kekuatan pembuktian dari akta otentik yang memiliki kekuatan pembuktian sempurna menjadi akta di bawah tangan yang memiliki kekuatan pembuktian yang tidak sempurna. Perjanjian kredit yang berbentuk akta di bawah tangan, beban pembuktian ada pada bank. Berbeda dengan akta otentik, kewajiban untuk membuktikan ada pada pihak yang menyangkal akta otentik tersebut. Perjanjian kredit atau tandatangannya yang tidak diakui oleh debitur dan dikabulkan hakim, bank tidak dapat mengeksekusi jaminan untuk hutang debitur. Bank juga harus mengeluarkan dana lebih untuk proses di pengadilan dan dapat merusak reputasi bank.

Kata Kunci: notaris, bank, perjanjian kredit, akta otentik, akta di bawah tangan.

\section{PENDAHULUAN}

Bank adalah sebuah badan usaha yang menjalankan kegiatan menghimpun danadari masyarakat dan menyalurkan kembali kepada pihak-pihak yang membutuhkan dalam bentuk kredit dan memberikan jasa dalam lalu lintas pembayaran. ${ }^{2}$ Menurut UndangUndang Nomor 10 Tahun 1998 tentang Perubahan Atas Undang-Undang Nomor 7 Tahun 1992 tentang Perbankan Tambahan Lembaran Negara Republik Indonesia Nomor 3790 atau disebut UU Perbankan, yang dimaksud dengan bank adalah "badan usaha yang menghimpun dana dari masyarakat dalam bentuk simpanan dan menyalurkannya kepada masyarakat dalam bentuk kredit dan atau bentuk-bentuk lainnya dalam rangka meningkatkan taraf hidup rakyat banyak". Penyaluran dana (fund lending) adalah kegiatan usaha meminjamkan dana kepada masyarakat dalam bentuk kredit (hutang). ${ }^{3}$ Pemberian kredit oleh bank didasarkan pada perjanjian yaitu perjanjian kredit. Menurut penjelasan dalam Pasal 1 angka (11) UU Perbankan, "kredit adalah penyediaan uang atau tagihan yang dapat dipersamakan dengan itu, berdasarkan persetujuan atau kesepakatan pinjam meminjam antara bank dengan pihak lain yang mewajibkan pihak peminjam untuk melunasi utangnya setelah jangka waktu tertentu dengan pemberian bunga".

Pada pasal-pasal dalam UU Perbankan memang tidak dijelaskan secara eksplisit mengenai ketentuan bentuk perjanjian kredit, namun jika melihat pada ketentuan dalam

\footnotetext{
${ }^{2}$ Hermansyah, Hukum Perbankan Nasional Indonesia, Jakarta, Kencana, 2008, hal. 8.

${ }^{3}$ Abdulkadir Muhammad dan Rilda Murniati, Lembaga Keuangan dan Pembiayaan, Bandung, Citra Aditya Bakti, 2000, hal. 58.
} 
penjelasannya, maka terlihat pada penjelasan Pasal 8 ayat (2) disebutkan bahwa perjanjian kredit dibuat dalam bentuk perjanjian tertulis. Hal itu juga diatur dalam Instruksi Presidium Kabinet No.15/EKA/10/1996 Surat Edaran Bank Indonesia Unit 1 no. 2/539/UPK/Pemb/1996 dan Surat Edaran Bank Indonesia No. 2/643/UPK/Pemb/1996 tentang Pedoman Kebijaksanaan di Bidang Perkreditan diinstruksikan, bahwa dalam pemberian kredit bentuk apapun bank-bank wajib mempergunakan akad perjanjian kredit.

Perjanjian kredit tertulis bisa berbentuk akta di bawah tangan maupun akta otentik. Perjanjian dalam bentuk akta di bawah tangan diatur dalam Pasal 1874 KUHPerdata. Akta di bawah tangan mempunyai kekuatan hukum pembuktian jika tanda tangan yang ada dalam akta tersebut diakui oleh yang menandatanganinya. Berbeda dengan akta otentik, akta otentik mempunyai kekuatan pembuktian yang sempurna, artinya, akta otentik dianggap sah dan benar tanpa perlu membuktikan atau menyelidiki keabsahan tanda tangan dari para pihak, kecuali ada yang dapat membuktikan sebaliknya, namun untuk akta otentik, jika ada yang menyangkal, pihak yang menyangkal itulah yang berkewajiban membuktikan ketidakbenaran yang ia maksudkan.

Notaris berwenang untuk membuat perjanjian kredit yang berbentuk akta otentik. ${ }^{4}$ Ketentuan mengenai kewenangan Notaris untuk membuat akta otentik diatur dalam Undang-Undang Nomor 2 Tahun 2014 tentang Perubahan Atas Undang-Undang Nomor 30 Tahun 2004 tentang Jabatan Notaris Tambahan Lembaran Negara Republik Indonesia Nomor 5491 atau disebut UUJN Pasal 1 angka 1.

Pasal 1868 KUHPerdata menyebutkan : "suatu akta otentik adalah suatu akta yang dibuat dalam bentuk yang ditentukan oleh undang-undang atau dihadapan pejabat umum yang berwenang untuk itu ditempat akta itu dibuat". Akta Notaris sebagai akta otentik berdasarkan Pasal 1868 KUHPerdata harus memenuhi syarat-syarat formal. ${ }^{5}$ Mengenai hal tersebut juga diperjelas di dalam UUJN yang membahas mengenai kewajiban Notaris yaitu Pasal 16 ayat (1) huruf $m$ yang menyebutkan bahwa dalam menjalankan jabatannya, Notaris wajib membacakan akta dihadapan penghadap dengan dihadiri paling sedikit 2 (dua) orang saksi. Ketentuan undang-undang di atas ternyata tidak sejalan dengan praktek di lapangan. Penulis telah mencoba meneliti dengan mewawancarai beberapa Notaris di Provinsi Daerah

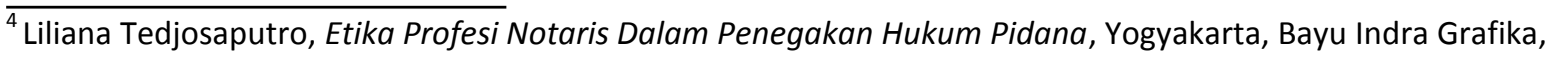
1995, hal. 84.

${ }^{5}$ R. Soegondo Notodisoerjo, 1993, Hukum Notariat di Indonesia Suatu Penjelasan, Jakarta, Raja Grafindo Persada, 1993, hal. 58.
} 
Istimewa Yogyakarta, bahwa banyak dilakukan penandatanganan perjanjian kredit yang tidak dilakukan dihadapan Notaris.

Penandatanganan perjanjian kredit yang berbentuk akta otentik yang tidak dilakukan dihadapan Notaris tentunya akan menimbulkan masalah jika terjadi wanprestasi oleh debitur. Pada prakteknya, terdapat beberapa Notaris melakukan penandatanganan akta perjanjian kredit tanpa kehadiran para pihak dihadapannya yang secara tegas melanggar ketentuan peraturan perundang-undangan dan konsekuensi hukum yang dihadapi bank jika hal itu dilakukan, perlu dilakukan penelitian lebih lanjut untuk dapat menemukan jawaban pasti yang dapat dipergunakan untuk pengetahuan masyarakat luas sebagai pembelajaran. Penulis dalam hal ini tertarik untuk meneliti mengenai permasalahan di atas sehingga dalam penyusunan tesis ini penulis akan meneliti lebih lanjut mengenai:

1. Mengapa Notaris melakukan penandatanganan akta perjanjian kredit tanpa kehadiran para pihak dihadapannya yang secara tegas melanggar ketentuan peraturan perundangundangan?

2. Konsekuensi hukum apa yang dihadapi bank sebagai kreditur akibat penurunan status perjanjian kredit dari akta otentik menjadi akta di bawah tangan karena ketidakhadiran para pihak di hadapan Notaris?

\section{METODOLOGI PENELITIAN}

Jenis penelitian ini yaitu normatif empiris. Penelitian hukum normatif empiris ini pada dasarnya merupakan penggabungan antara pendekatan hukum normatif dengan adanya penambahan berbagai unsur empiris. Metode hukum normatif merupakan penelitian kepustakaan yaitu penelitian terhadap data sekunder. ${ }^{6}$ Penelitian hukum empiris yaitu penelitian lapangan terhadap data primer. Metode penelitian normatif empiris mengenai implementasi ketentuan hukum normatif (undang-undang) dalam aksinya pada setiap peristiwa hukum tertentu yang terjadi dalam suatu masyarakat. ${ }^{7}$

Penelitian ini bersifat deskriptif yaitu satu jenis penelitian yang tujuannya untuk menyajikan gambaran lengkap mengenai suatu permasalahan atau dimaksudkan untuk eksplorasi dan klarifikasi mengenai suatu fenomena atau kenyataan sosial, dengan jalan

\footnotetext{
${ }^{6}$ Ronny Hanitijo Soemitro, Metodologi Penelitian Hukum dan Jurimetri, Jakarta, Ghalia Indonesia, 1990, hal. 11.

${ }^{7}$ Soejono dan H Abdurrahman, 1999, Metode Penelitian Suatu Pemikiran dan Penerapan, Jakarta Rineke Cipta, 1999, hal. 110.
} 
mendeskripsikan sejumlah variabel yang berkenaan dengan masalah dan unit yang diteliti antara fenomena yang diuji.

Analisis data pada penelitian ini menggunakan metode kualitatif yaitu pemilihan terhadap data yang diperoleh dari penelitian berdasarkan mutu atau kualitasnya sehingga dihasilkan suatu uraian yang relevan yang dapat menjawab pertanyaan dalam permasalahan-permasalahan yang ada, dengan jelas dan lengkap berdasarkan penelitian kepustakaan kemudian disusun secara sistematis sehingga diperoleh kesimpulan. ${ }^{8}$

Penyampaian hasil penelitian tersebut kemudian diuraikan menggunakan metode deskriptif. Metode deskriptif dapat diartikan sebagai prosedur pemecahan masalah yang diselidiki dengan menggambarkan keadaan objek/subjek penelitian pada saat sekarang berdasarkan fakta-fakta yang tampak atau sebagaimana adanya. ${ }^{9}$ Pada penelitian ini digunakan metode deskriptif yang dilakukan dengan memaparkan keadaan yang ada pada obyek penelitian, kemudian menganalisisnya dengan menjelaskan data dan informasi yang didapat dari segi teori maupun hasil penelitian untuk menjawab permasalahan.

\section{PEMBAHASAN}

\section{A. Faktor Penyebab Notaris Menandatangani Akta Perjanjian Kredit Tanpa Kehadiran Para Pihak Dihadapannya yang Secara Tegas Melanggar Ketentuan Peraturan Perundang-Undangan}

\section{a. Hasil Penelitian}

Kredit dengan perjanjian kredit yang berbentuk akta otentik yang dibuat oleh Notaris, tentunya harus ditandatangani dihadapan Notaris yang membuatnya. Hal tersebut diatur dalam Pasal 1868 KUHPerdata. Akta Notaris sebagai akta otentik berdasarkan Pasal 1868 KUHPerdata harus memenuhi syarat-syarat formal. ${ }^{10}$ Mengacu pada ketentuan pasal tersebut, maka suatu akta otentik harus dibuat dihadapan pejabat umum yang berwenang, sehingga perjanjian kredit yang berbentuk akta otentik harus dibuat dihadapan Notaris, begitu pula pada akta di bawah tangan yang dilegalisasi Notaris, harus ditandatangani dihadapan Notaris.

\footnotetext{
${ }^{8}$ Philips Dillah dan Suratman, 2012, Metode Penelitian Hukum, Bandung, Alfabeta, 2012, hal. 145-146.

${ }^{9}$ Hadari Nawawi, Metode Penelitian Bidang Sosial, Yogyakarta, Gadjah Mada University Press, 1990, hal. 63.

${ }^{10}$ R. Soegondo Notodisoerjo, Loc. Cit.
} 
Pada prakteknya, berdasarkan penelitian yang dilakukan dengan wawancara pada responden yaitu Notaris-Notaris di Daerah Istimewa Yogyakarta dan pegawai dari beberapa bank di Daerah Istimewa Yogyakarta, penulis menemukan fakta bahwa terdapat beberapa kasus perjanjian kredit yang berbentuk akta di bawah tangan yang dilegalisasi Notaris maupun perjanjian kredit yang berbentuk akta otentik tidak dibacakan dan tidak ditandatangani dihadapan Notaris yang melegalisasi maupun yang membuatnya.

Hasil wawancara dengan Notaris I, diketahui bahwa faktor yang menyebabkan tidak ditandatanganinya perjanjian kredit yang berbentuk akta di bawah tangan yang dilegalisasi Notaris maupun perjanjian kredit yang berbentuk akta otentik dihadapan Notaris yang bersangkutan yaitu karena terlalu banyak akta yang harus Notaris I buat. Hasil wawancara dengan Notaris I memberikan jawaban bahwa, Notaris I banyak melakukan kerjasama dengan beberapa bank di Yogyakarta sehingga akta yang berkaitan dengan perbankan yang harus ia persiapkan sangatlah banyak dan menguras waktu. Menurutnya, akan lebih memudahkan apabila penandatanganan perjanjian kredit dilakukan tanpa kehadirannya. Apalagi, pihak bank dalam hal ini menyetujui penandatanganan perjanjian kredit tidak dihadapan Notaris melainkan dihadapan pegawai bank nya saja, sehingga Notaris I tetap menjalankan hal tersebut dengan dasar persetujuan dari bank yang bersangkutan. ${ }^{11}$

Berbeda dengan Notaris I, berdasarkan wawancara dengan Notaris II, diketahui bahwa faktor yang menyebabkan tidak ditandatanganinya perjanjian kredit yang berbentuk akta di bawah tangan yang dilegalisasi Notaris maupun perjanjian kredit yang berbentuk akta otentik dihadapan Notaris yang bersangkutan yaitu dikarenakan permintaan pihak bank. Berdasarkan keterangan Notaris II, pihak bank menilai bahwa penandatanganan perjanjian kredit akan lebih mempermudah calon debitur jika dilakukan di bank tanpa perlu hadir dikantor Notaris dan menghadap Notaris II. Pada proses permohonan kredit, calon debitur perlu memenuhi beberapa persyaratan tertentu. Penandatanganan perjanjian kredit dilaksanakan di bank, menurut pihak bank akan mempermudah proses permohonan kredit karena selain penandatanganan perjanjian kredit, calon debitur juga dapat sekaligus memenuhi persyaratan dalam permohonan kredit di bank yang bersangkutan jika ada persyaratan yang belum terpenuhi, jadi diharapkan dapat mempermudah calon debitur dan mempercepat proses permohonan kreditnya. Jarak antara bank dengan kantor Notaris II

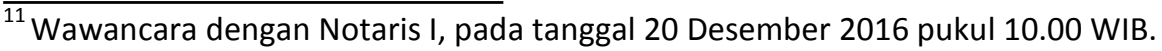


yang jauh dan penyesuaian waktu untuk bertemu Notaris II yang sulit, juga menjadi alasan pihak bank menghendaki penandatanganan perjanjian kredit dilakukan di bank, agar calon debitur tidak merasa direpotkan dengan prosedur yang ada dan permohonan kreditnya dapat segera diselesaikan. ${ }^{12}$ Berdasarkan wawancara dengan account officer bank tersebut, memang benar pelaksanaan penandatangan perjanjian kredit dilakukan di bank dengan tanpa dihadapan Notaris II. ${ }^{13}$

Hampir sama dengan Notaris II, berdasarkan wawancara dengan Notaris III, diketahui bahwa faktor yang menyebabkan tidak ditandatanganinya perjanjian kredit yang berbentuk akta di bawah tangan yang dilegalisasi Notaris maupun perjanjian kredit yang berbentuk akta otentik dihadapan Notaris yang bersangkutan yaitu dikarenakan permintaan dari pihak bank. Menurut keterangan Notaris III, pihak bank memiliki target besar dalam memenuhi kredit kepada calon debiturnya, sehingga bank dalam hal ini terkesan banyak memaksakan dalam memenuhi pencapaian targetnya. Salah satu contohnya yaitu penandatanganan perjanjian kredit yang dilakukan di bank maupun di rumah yang akan dijadikan jaminan kredit (dalam hal Kredit Pemilikan Rumah). Tujuannya agar calon debitur tidak merasa direpotkan dan akan tetap menggunakan bank tersebut untuk pengajuan kreditnya. Notaris III mengatakan telah memberikan peringatan kepada bank bahwa tindakannya tersebut dapat memberikan risiko terhadap bank karena tidak memenuhi aturan yang berlaku, namun pihak bank tidak mempermasalahkannya dan tetap melaksanakannya menurut keinginan bank. Notaris III berkenan melaksanakan penandatangan perjanjian kredit yang dibuatnya tanpa kehadirannya dengan dasar bahwa pihak bank menjamin tidak akan menuntut maupun mempermasalahkan hal tersebut kepada Notaris III jika suatu saat terdapat masalah perjanjian kredit tersebut. ${ }^{14}$ Terhadap hal ini penulis mencoba mewawancarai account officer bank tersebut dan menanyakan perihal perjanjian kredit. Menurut keterangan account officer bank tersebut, perjanjian kredit dan segala berkaitan dengan proses permohonan kredit dapat dilaksanakan di bank maupun di rumah calon debitur tanpa harus dihadapan Notaris, sesuai permintaan calon debitur. Pihak bank yang

\footnotetext{
$\overline{12}$ Wawancara dengan Notaris II, pada tanggal 24 Desember 2016 pukul 08.00 WIB.

${ }^{13}$ Wawancara dengan Account Officer Bank II, pada tanggal 24 Desember 2016 pukul 12.00 WIB.

${ }^{14}$ Wawancara dengan Notaris III, pada tanggal 26 Desember 2016 pukul 15.00 WIB.
} 
Vol 2, No. (2019): Law, Development \& Justice Review, Mei 2019. e-ISSN: 2655-1942

akan datang menemui calon debitur dengan membawa kelengkapan proses permohonan kredit. $^{15}$

\section{b. Pembahasan}

Akta otentik maupun akta di bawah tangan yang dilegalisasi Notaris wajib dibacakan dan dijelaskan oleh Notaris serta ditandatangani dihadapan Notaris yang bersangkutan. Hal ini seperti yang telah disebutkan dalam Pasal 16 ayat (1) huruf m UUJN. Pada Pasal 44 ayat (1) UUJN juga dijelaskan bahwa segera setelah akta dibacakan, akta tersebut ditandatangani oleh setiap penghadap, saksi, dan Notaris, kecuali apabila ada penghadap yang tidak dapat membubuhkan tanda tangan dengan menyebutkan alasannya. Sanksi dilanggarnya pasal tersebut dijelaskan pada ayat (5) nya yang berbunyi, "Pelanggaran terhadap ketentuan sebagaimana dimaksud pada ayat (1), ayat (2), ayat (3), dan ayat (4) mengakibatkan suatu akta hanya mempunyai kekuatan pembuktian sebagai akta di bawah tangan dan dapat menjadi alasan bagi pihak yang menderita kerugian untuk menuntut penggantian biaya, ganti rugi, dan bunga kepada Notaris."

Hal ini berlaku pada perjanjian kredit yang dibuat dalam bentuk akta otentik. Pembacaan akta yang tidak dilakukan oleh Notaris tanpa dilakukan syarat pengecualian seperti yang dijelaskan dalam Pasal 16 ayat (7) UUJN dan penandatanganan perjanjian kredit yang berbentuk akta otentik tersebut tidak dilakukan dihadapan Notaris, maka perjanjian kredit yang berbentuk akta otentik tersebut hanya akan memiliki kekuatan pembuktian seperti akta di bawah tangan. Berdasarkan Pasal 1875 KUHPerdata maka ada kemungkinan akta di bawah tangan tidak diakui, oleh karena itu suatu akta di bawah tangan tidak memiliki kekuatan pembuktian lahiriah.

Hal ini tentu saja dapat merugikan pihak bank karena perjanjian kredit yang dibuat dalam bentuk akta otentik dengan maksud agar memiliki pembuktian yang sempurna, menjadi hanya memiliki pembuktian seperti akta di bawah tangan. Begitu pula pada perjanjian kredit yang berbentuk akta di bawah tangan yang kemudian dilegalisasi, legalisasinya menjadi percuma, sedangkan bank sudah mengeluarkan dana untuk pembuatan akta otentik maupun legalisasi.

Kasus yang terjadi pada Notaris I, Notaris II dan Notaris III, pihak bank telah mengetahui dan menyetujui tindakan Notaris-Notaris tersebut untuk tidak menandatangani

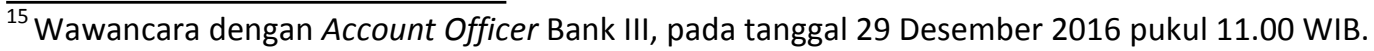


perjanjian kredit baik yang berbentuk legalisasi maupun akta otentik, dihadapan para pihaknya. Penulis dapat simpulkan bahwa tindakan bank dalam memberikan persetujuan untuk dilakukan penandatangan akta perjanjian kredit baik yang berbentuk legalisasi maupun akta otentik, tidak dihadapan Notaris, adalah kecerobohan bank. Terlihat disini pihak bank kurang memahami akibat hukum yang dapat ditimbulkan dari penandatangan akta perjanjian kredit baik yang berbentuk legalisasi maupun akta otentik yang dilakukan tidak dihadapan Notaris, sehingga dapat merugikan bank.

Persetujuan bank dalam hal ini untuk menandatangani akta perjanjian kredit baik yang berbentuk legalisasi maupun akta otentik, tidak dihadapan Notaris, tidak dapat mengeliminasi ketentuan peraturan perundang-undangan yang melarang hal tersebut. Asas kebebasan berkontrak yang berlaku bagi setiap perjanjian tidak berarti dapat diterapkan sebebas-bebasnya atau tanpa batas. Asas kebebasan berkontrak harus dilaksanakan dengan itikad baik dari para pihaknya. Maksud dari itikad baik dalam menjalankan perjanjian adalah perikatan yang ada di dalamnya dijalankan tanpa melanggar ketentuan peraturan perundang-undangan, kesusilaan dan kepatutan. Meskipun bank dalam hal ini sebagai pihak yang akan menerima kerugian atas perbuatan Notaris yang tidak melaksanakan penandatanganan akta perjanjian kredit baik yang berbentuk legalisasi maupun akta otentik dihadapannya, telah memberikan persetujuannya, yang dapat diartikan bank telah memahami dan bersedia menanggung segala akibat dari persetujuannya, namun dalam hal ini ketentuan peraturan perundang-undanganlah yang akan tetap berlaku, karena perjanjian antara bank dengan Notaris mengenai persetujuan ini melanggar ketentuan peraturan perundang-undangan, sehingga asas kebebasan berkontrak tidak dapat diterapkan.

Notaris I, Notaris II dan Notaris III meskipun telah diizinkan pihak bank untuk dilakukan penandatanganan akta perjanjian kredit baik yang berbentuk legalisasi maupun akta otentik, tidak dihadapannya, baik sengaja maupun tidak, tidak seharusnya Notaris I, Notaris II dan Notaris III melakukan hal itu, karena telah jelas melanggar ketentuan UUJN Pasal 16 ayat (1) huruf $m$ jo Pasal 44 ayat (1). Selain melanggar UUJN, Notaris I, Notaris II dan Notaris III juga tidak melaksanakan kewajibannya menurut Kode Etik Notaris pada Pasal 3 ayat (14) yang menyebutkan bahwa "salah satu kewajiban Notaris adalah menjalankan jabatan Notaris terutama dalam pembuatan, pembacaan dan penandatanganan akta dilakukan di kantornya, kecuali alasan-alasan yang sah". Sanksi terhadap pelanggaran terhadap UUJN 
Pasal 16 ayat (1) huruf m disebutkan dalam UUJN Pasal 16 ayat (11) bahwa "Notaris yang melanggar akan dikenakan sanksi peringatan tertulis, pemberhentian sementara, pemberhentian dengan hormat, dan pemberhentian dengan tidak hormat". Sanksi atas pelanggaran terhadap UUJN Pasal 44 ayat (1) adalah "akta menjadi hanya mempunyai kekuatan pembuktian sebagai akta di bawah tangan dan dapat menjadi alasan bagi pihak yang menderita kerugian untuk menuntut penggantian biaya, ganti rugi, dan bunga kepada Notaris".

Notaris I, Notaris II dan Notaris III juga melanggar Kode Etik Notaris Pasal 4 ayat (5) yang menjelaskan mengenai larangan Notaris untuk menandatangani akta yang proses pembuatan minutanya telah dipersiapkan oleh pihak lain dan mengirimkan minuta kepada klien untuk ditanda tangani. Sanksi bagi Notaris yang melanggar Kode Etik Notaris disebutkan dalam Pasal 6 ayat (1) Kode Etik Notaris yang menyebutkan bahwa sanksi yang dikenakan terhadap anggota yang melakukan pelanggaran Kode Etik dapat berupa teguran, peringatan, onzetting (pemecatan) dari keanggotaan Perkumpulan atau pemberhentian dengan tidak hormat dari keanggotaan Perkumpulan.

\section{B. Konsekuensi Yuridis yang Dihadapi Bank Sebagai Kreditur Akibat Penurunan Status Perjanjian Kredit dari Akta Otentik Menjadi Akta di Bawah Tangan karena Ketidakhadiran Para Pihak di Hadapan Notaris}

\section{a. Hasil Penelitan}

Perjanjian kredit yang berbentuk akta otentik maupun akta di bawah tangan yang dilegalisasi Notaris wajib dibacakan dan dijelaskan oleh Notaris serta ditandatangani dihadapan Notaris yang bersangkutan. Perjanjian kredit yang sengaja dibuat dengan bentuk akta otentik dimaksudkan agar kekuatan pembuktian perjanjian kreditnya menjadi sempurna, sehingga dapat menghindari kemungkinan-kemungkinan terburuk yang dapat dihadapi bank. Menurunnya status perjanjian kredit yang berbentuk akta otentik karena penandatanganan perjanjian kreditnya tidak dihadapan Notaris membuat pembuatan akta otentik menjadi percuma dan perjanjian kredit yang dimiliki bank menjadi tidak lagi mempunyai kekuatan pembuktian yang sempurna. Perjanjian kredit yang berbentuk akta di bawah tangan rentan akan masalah dalam hal terjadi wanprestasi oleh debitur. Permasalahan yang dapat terjadi pada perjanjian kredit yaitu seperti pemalsuan identitas, pemaksaan dalam penandatanganan, pemalsuan tanda tangan, dan lain sebagainya. 
Salah satu kasus yang terjadi di Yogyakarta yaitu kasus yang terjadi pada bank $\mathrm{X}$. Nyonya A berhutang kepada Bank $\mathrm{X}$ dengan jaminan rumah yang digunakan untuk usahanya. Rumah tersebut merupakan harta bersama dengan suaminya yaitu Tuan B, oleh karena itu persetujuan Tuan B dalam perjanjian kredit diperlukan. Perjanjian kredit dibuat dalam bentuk akta otentik oleh Notaris I. Pada saat penandatanganan perjanjian kredit, Notaris I tidak bisa hadir sehingga tanda tangan hanya dilakukan di hadapan pegawai Bank X. Permasalahan terjadi pada saat terjadi wanprestasi oleh Nyonya A sebagai debitur. Kredit macet dan Nyonya A tidak dapat melunasi hutangnya sehingga rumah yang digunakan sebagai jaminan atas hutangnya harus dieksekusi Bank X. Tuan B yang selama ini bekerja diluar kota, merasa tidak mengetahui mengenai hutang tersebut dan terkejut mengetahui rumahnya akan disita Bank $X$ sehingga ia menggugat di pengadilan, menuntut pembatalan perjanjian kreditnya. Setelah diselidiki baru diketahui bahwa ternyata pada saat penandatanganan perjanjian kredit, yang hadir sebagai suami dari Nyonya $A$ untuk memberikan tanda tangan persetujuan bukanlah Tuan B meskipun data-data Tuan B lah yang digunakan untuk melancarkan permohonan kredit tersebut. Pada persidangan tersebut Tuan B dapat membuktikan bahwa perjanjian kreditnya cacat karena tidak dilaksanakan dihadapan Notaris I dan dengan alibinya ia pun dapat membuktikan bahwa memang bukan dia yang memberikan tanda tangan persetujuan, sehingga ia mengingkari perjanjian kredit tersebut. Bank $X$ menjadi dirugikan dalam hal ini karena tidak dapat mengeksekusi rumah yang menjadi jaminan kreditnya. ${ }^{16}$

\section{b. Pembahasan}

Menurunnya status perjanjian kredit yang berbentuk akta otentik atau akta di bawah tangan yang dilegalisasi Notaris tentunya dapat memicu kerugian bagi bank. Hal ini dapat terjadi jika debitur bank melakukan wanprestasi dan mencari celah hukum dengan mengajukan gugatan kepada bank yang menyatakan bahwa perjanjian kreditnya tidak dilaksanakan sesuai aturan yang berlaku, dalam hal ini, perjanjian kredit yang berbentuk akta otentik, tidak ditandatangani dihadapan Notaris yang membuatnya atau perjanjian kredit yang berbentuk akta di bawah tangan yang dilegalisasi Notaris namun penandatanganannya tidak dilakukan dihadapan Notaris yang melegalisasi, sehingga perjanjian kreditnya menurun statusnya menjadi hanya akta di bawah tangan.

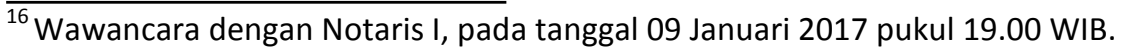


Akta di bawah tangan tidak memiliki kekuatan pembuktian lahiriah. Kekuatan pembuktian yang terdapat pada suatu akta di bawah tangan adalah kekuatan pembuktian formil, yaitu apabila tanda tangan di bawah akta itu diakui kebenarannya oleh para pihak yang membuat perjanjian di bawah tangan. Menjadi suatu kelemahan dari akta di bawah tangan bahwa apabila terjadi wanprestasi oleh debitur, yang pada akhirnya akan diambil tindakan hukum melalui proses pengadilan, maka apabila debitur yang bersangkutan menyangkal atau memungkiri tanda tangannya, akan berakibat mentahnya kekuatan hukum akta di bawah tangan yang telah dibuat tersebut. ${ }^{17}$

Berdasarkan Pasal 1875 KUHPerdata maka ada kemungkinan akta di bawah tangan tidak diakui. Perjanjian kredit yang berbentuk akta di bawah tangan, jika tidak diakui oleh debiturnya, maka beban pembuktian ada pada bank. Akta di bawah tangan yang tidak diakui harus dibuktikan oleh pihak yang membawanya sebagai alat bukti. Berbeda dengan perjanjian kredit yang berbentuk akta otentik, jika terdapat penyangkalan terhadap akta otentik, kewajiban untuk membuktikan ada pada pihak yang menyangkal akta otentik tersebut, sehingga dalam hal ini, jika dibawa ke pengadilan, maka debitur lah yang harus membuktikan bahwa akta otentik tersebut tidak benar

Perjanjian kredit yang berbentuk akta di bawah tangan juga memiliki kekurangan lain, yakni apabila terjadi permasalahan dengan perjanjian kreditnya, maka yang bertanggung jawab adalah pihak bank sendiri. Berbeda dengan perjanjian kredit yang berbentuk akta otentik, yang berkewajiban untuk bertanggungjawab atas kerugian yang timbul karenanya adalah Notaris yang membuatnya.

Perjanjian kredit yang turun statusnya menjadi akta di bawah tangan, memiliki kemungkinan-kemungkinan untuk menimbulkan masalah dikemudian hari. Hal ini dapat timbul jika terjadi wanprestasi. Perjanjian kredit yang turun statusnya menjadi akta di bawah tangan karena tidak ditandatangani dihadapan Notaris, berdasarkan Pasal 1877 KUHPerdata, perlu ada pembuktian lebih lanjut di pengadilan jika debitur tidak mengakuinya. Kemungkinan debitur tidak mengakui perjanjian kredit tersebut bisa dikarenakan suatu itikad tidak baik atau memang tidak mengetahui perihal perjanjian kredit tersebut, seperti pada kasus yang pernah terjadi pada Bank X. Tuan B yang tidak mengetahui mengenai perjanjian kredit antara istrinya dengan Bank $X$, menuntut

\footnotetext{
${ }^{17}$ H. R. Daeng Naja, Hukum Kredit dan Bank Garansi, Bandung, PT Citra Aditya Bakti, 2005, hal. 184.
} 
pembatalan perjanjian kreditnya karena ia merasa tidak pernah memberikan persetujuan mengenai perjanjian kredit tersebut. Disini terlihat ada itikad tidak baik dari Nyonya B karena ia telah memalsukan tanda tangan Tuan B dengan menghadirkan orang lain yang mengaku sebagai Tuan B. Perjanjian kredit yang dibuat dalam bentuk akta otentik tersebut juga tidak dihadiri oleh Notaris I, sehingga dapat dijadikan alasan untuk pembatalan keotentikannya. Pembatalan keontentikan perjanjian kredit tersebut menyebabkan perjanjian kredit hanya memiliki kekuatan pembuktian seperti akta di bawah tangan. Hal ini memberi celah untuk debitur melakukan pengingkaran terhadap perjanjian kredit tersebut. Ketidakhadiran Notaris I selain menyebabkan perjanjian kredit yang berbentuk akta otentik tersebut menjadi turun statusnya hanya menjadi akta di bawah tangan, juga melancarkan aksi Nyonya A melakukan pemalsuan tanda tangan Tuan B. Pihak bank yang menjadi saksi dalam penandatanganan perjanjian kredit tersebut juga tidak meneliti dan memastikan bahwa orang yang hadir untuk memberikan persetujuan itu adalah benar Tuan B, yang tugas tersebut seharusnya adalah menjadi kewajiban Notaris I untuk melaksanakannya.

Turunnya status perjanjian kredit dapat memicu kerugian bagi bank, karena terdapat celah untuk seseorang mempermasalahkan hal tersebut. Pada kasus di atas, Bank X pun menderita kerugian. la tidak bisa mengeksekusi jaminan kreditnya dikarenakan gugatan Tuan B dikabulkan oleh hakim. Terbuktinya perjanjian kredit yang tidak dilaksanakan dengan sebagaimana mestinya, menyebabkan perjanjian kredit berakhir dengan penghapusan perjanjian kreditnya, dimana dapat berdampak pada perjanjian penjaminannya. Menurut $\mathrm{R}$. Setiawan, perjanjian dapat berakhir salah satunya karena karena putusan hakim. Perjanjian hapus karena putusan hakim apabila salah satu pihak menuntut pengakhiran perjanjian dan dikabulkan oleh hakim. ${ }^{18}$

Hapusnya perjanjian pokok dapat menyebabkan hapusnya perjanjian accessoirnya. Hapusnya perjanjian penjaminan, menyebabkan bank tidak dapat mengeksekusi benda jaminan untuk melunasi piutangnya jika debitur wanprestasi. Bank juga tidak dapat memberikan dorongan kepada debitur untuk memenuhi janjinya, khususnya mengenai pembayaran kembali.

Pihak-pihak yang berperan penting dalam terjadinya pelanggaran penandatanganan perjanjian kredit yang berbentuk akta otentik yaitu bank dan Notaris. Bank, jika dalam hal ini

\footnotetext{
${ }^{18}$ R. Setiawan, Pokok-Pokok Hukum Perikatan, Bandung, Putra Bardin, 1999, hal. 69.
} 
tidak memberikan persetujuan, atau dalam arti lain bahwa pelanggaran penandatangan perjanjian kredit yang berbentuk akta otentik hanya berdasarkan inisiatif dari Notarisnya sendiri, maka jika bank menderita kerugian karenanya, bank dapat menggugat Notaris yang melakukan pelanggaran tersebut. Gugatan tersebut dapat dilakukan dengan dasar ketentuan dalam UUJN Pasal 44 ayat (5) yang menyebutkan bahwa pelanggaran terhadap ketentuan sebagaimana dimaksud pada ayat (1), ayat (2), ayat (3), dan ayat (4) mengakibatkan suatu akta hanya mempunyai kekuatan pembuktian sebagai akta di bawah tangan dan dapat menjadi alasan bagi pihak yang menderita kerugian untuk menuntut penggantian biaya, ganti rugi, dan bunga kepada Notaris.

Berbeda apabila dalam melakukan pelanggaran penandatangan perjanjian kredit yang berbentuk akta otentik adalah berdasarkan persetujuan bank atau bahkan permintaan dari bank. Meskipun Notaris yang melakukan pelanggaran tersebut tetap tidak dapat dipungkiri bahwa ia telah melakukan suatu pelanggaran terhadap ketentuan peraturan perundangundangan, namun dalam hal ini Notaris dapat membela diri dengan alasan pelanggaran tersebut ia dilakukan karena mendapat persetujuan atau permintaan dari bank. Notaris yang bersangkutan jika dapat membuktikan terdapat keterlibatan bank dalam pelanggaran ini, bisa menambah pertimbangan hakim untuk tidak membebankan semua kerugian hanya padanya. Hal ini dapat mempengaruhi besar kerugian yang harus ditanggung oleh bank, meskipun semuanya kembali pada putusan hakim.

Konsekuensi lain yang dapat diterima bank akibat penandatangan perjanjian kredit yang berbentuk akta otentik tidak dilakukan dihadapan Notaris yakni bank harus mengeluarkan dana untuk proses di pengadilan. Persidangan yang lama dan berbelit-belit dapat merugikan bank karena bank perlu mengeluarkan biaya yang tidak sedikit untuk Penasehat Hukum yang mewakilinya. Pelanggaran yang dilakukan bank yang berujung pada proses di pengadilan juga dapat merusak nama baik bank, apabila kasus ini sampai pemberitaannya tersebar ke khalayak luas, maka reputasi bank akan turun. Masyarakat akan bisa mengetahui bahwa bank bertindak ceroboh dan tidak teliti dalam menjalankan usahanya sehingga tidak menutup kemungkinan masyarakat menjadi tidak percaya pada bank. Bank dalam menjalankan usahanya berpegang pada prinsip kepercayaan masyarakat, apabila masyarakat tidak lagi percaya pada bank, maka hal tersebut dapat merusak perekonomian bank. 


\section{SIMPULAN DAN SARAN}

a. Faktor penyebab Notaris menandatangani akta perjanjian kredit tanpa kehadiran para pihak dihadapannya yang secara tegas melanggar ketentuan peraturan perundangundangan yaitu dikarenakan terlalu banyak akta yang harus Notaris buat dan hal itu dilakukan karena telah mendapat persetujuan dari bank yang bersangkutan dan juga dikarenakan permintaan pihak bank.

b. Konsekuensi hukum yang dihadapi bank sebagai kreditur akibatpenurunan status perjanjian kredit dari akta otentik menjadi akta di bawah tangan karena ketidakhadiran para pihak di hadapan Notaris, yaitu terjadinya penurunan kekuatan pembuktian dari akta otentik yang memiliki kekuatan pembuktian sempurna menjadi akta di bawah tangan yang memiliki kekuatan pembuktian yang tidak sempurna. Perjanjian kredit yang berbentuk akta di bawah tangan, jika tidak diakui oleh debiturnya, maka beban pembuktian ada pada bank. Akta di bawah tangan yang tidak diakui harus dibuktikan oleh pihak yang membawanya sebagai alat bukti. Berbeda dengan perjanjian kredit yang berbentuk akta otentik, jika terdapat penyangkalan terhadap akta otentik, kewajiban untuk membuktikan ada pada pihak yang menyangkal akta otentik tersebut. Debitur lah yang harus membuktikan bahwa akta otentik tersebut tidak benar, jika dalam hal ini dibawa ke pengadilan. Turunnya status perjanjian kredit yang berbentuk akta otentik dapat berisiko menimbulkan masalah bagi bank jika debitur wanprestasi. Perjanjian kredit atau tandatangannya yang tidak diakui oleh debitur dan dikabulkan hakim, bank tidak dapat mengeksekusi jaminan untuk hutang debitur. Bank juga harus mengeluarkan dana lebih untuk proses di pengadilan dan dapat merusak reputasi bank.

c. Notaris yang ditunjuk dan dipercaya oleh bank untuk membuat perjanjian kredit yang berbentuk akta otentik maupun yang melegalisasi perjanjian kredit yang di bawah tangan seharusnya lebih berhati-hati dengan tidak menyanggupi permintaan bank dalam melaksanakan penandatanganan perjanjian kredit tidak dihadapannya karena dapat merugikan bank, dan juga melanggar ketentuan UUJN dan Kode Etik Notaris. Persetujuan bank dalam hal ini untuk menandatangani akta perjanjian kredit baik yang berbentuk legalisasi maupun akta otentik, tidak dihadapan Notaris, tidak dapat mengeliminasi ketentuan peraturan perundang-undangan yang melarang hal tersebut. 
Vol 2, No. (2019): Law, Development \& Justice Review, Mei 2019. e-ISSN: 2655-1942

d. Bank seharusnya bisa lebih berhati-hati dalam menjalankan usahanya dengan tidak melaksanakan perjanjian kredit yang berbentuk akta otentik tidak dihadapan Notaris, karena membuat akta otentiknya menjadi percuma, sehingga ketika terjadi wanprestasi, memberikan celah bagi debitur menyangkal perjanjian kreditnya, yang dapat merugikan bank. Bank juga harus berhati-hati dalam melaksanakan usahanya terutama dalam pembuatan perjanjian kredit dimana harus memastikan betul pihak-pihak yang menandatangani perjanjian kreditnya agar kejadian pada contoh kasus di atas tidak terulang.

\section{DAFTAR PUSTAKA}

Ashshofa, Burhan, 2004, Metode Penelitian Hukum, Jakarta: Rineka Cipta.

Dillah, Philips dan Suratman, 2012, Metode Penelitian Hukum, Bandung: Alfabeta.

Hermansyah, 2008, Hukum Perbankan Nasional Indonesia, Jakarta: Kencana.

Muhammad, Abdulkadir dan Rilda Murniati, 2000, Lembaga Keuangan dan Pembiayaan, Bandung: Citra Aditya Bakti.

Nawawi, Hadari, 1990, Metode Penelitian Bidang Sosial, Yogyakarta: Gadjah Mada University Press.

Naja, H. R. Daeng, 2005, Hukum Kredit dan Bank Garansi, Bandung: PT Citra Aditya Bakti. Notodisoerjo, R. Soegondo, 1993, Hukum Notariat di Indonesia Suatu Penjelasan, Jakarta: Raja Grafindo Persada.

Setiawan, R., 1999, Pokok-Pokok Hukum Perikatan, Bandung: Putra Bardin.

Soemitro, Ronny Hanitijo, 1990, Metodologi Penelitian Hukum dan Jurimetri, Jakarta: Ghalia Indonesia.

Soejono dan H Abdurrahman, 1999, Metode Penelitian Suatu Pemikiran dan Penerapan, Jakarta: Rineke Cipta.

Soekanto, Soerjono dan Sri Mamudji, 2007, Penelitian Hukum Normatif, Jakarta: PT Raja Grafindo Persada.

Sunggono, Bambang, 2006, Metodologi Penelitian Hukum, Jakarta: PT Raja Grafindo Persada.

Suryabrata, Sumadi, 1992, Metodologi Penelitian, Jakarta: Rajawali Pers.

Tedjosaputro, Liliana, 1995, Etika Profesi Notaris Dalam Penegakan Hukum Pidana, Yogyakarta: Bayu Indra Grafika. 